\title{
LOS PÁJAROS
}

el atardecer engaña a los pájaros y los hace cantar

por un momento despiertan del día, de la vigilia

y creyendo que se trata del amanecer

había una vez un pájaro que

rompen irreflexivamente a cantar

y oyéndose unos a otros, además

se consideran con el derecho a seguirlo haciendo

pese a su corta vida

y cantan aún más por un rato

nunca quiso cantar con sus compañeros

hasta que la oscuridad resulta cosa seria

en los atardeceres

y las marcas de luz del amanecer se hacen esperar

entonces se hace evidente que se dirigen hacia la noche

y que hacían del atardecer un alba

y una especie de vergüenza por haber sido engañados los acomete

en los atardeceres

[de súbito]

y los hace callar

nunca quiso cantar con sus compañeros

y al callarse todos, todos se callan

porque sabía que se engañaban 
porque saben que se han equivocado

y prefieren dormirse para no pensar en eso

y que tomaban el atardecer por un alba

y lo hacen, de hecho, inmediatamente

- luego murió

y apenas y se mueven durante la noche

como todos los pájaros

en las mañanas en cambio nada los desmiente

como todos los pájaros

y cantan y cantan hasta que se cansan

y nunca jamás ninguno

y sus días son largos y ocupados a tal grado que

olvidados de todo

había una vez un pájaro que

caen una vez más en el engaño

y otra vez vuelven a cantar sus canciones al atardecer

hasta la fecha

y durante un largo rato siguen haciendo ruido

ningún pájaro siguió su ejemplo

entregados descuidadamente a su ilusión

porque no tienen memoria

(ni vergüenza)

y jamás aprenderán de sus errores 